\title{
Implementation of e-marketing via Instragram on the sustainability of MSMEs in the face of the Covid-19 Pandemic in Baubau City
}

\author{
Wa Ode Rhevi Silviani.A ${ }^{\mathrm{a}, 1, *}$ \\ ${ }^{a}$ Communication Sciences Study, Universitas Muhammadiyah Buton, Jl. Betoambari, Lanto, Batupoar, Kota Bau-Bau, Sulawesi Tenggara 93724 \\ ${ }^{1}$ revy5445@gmail.com* \\ * corresponding author
}

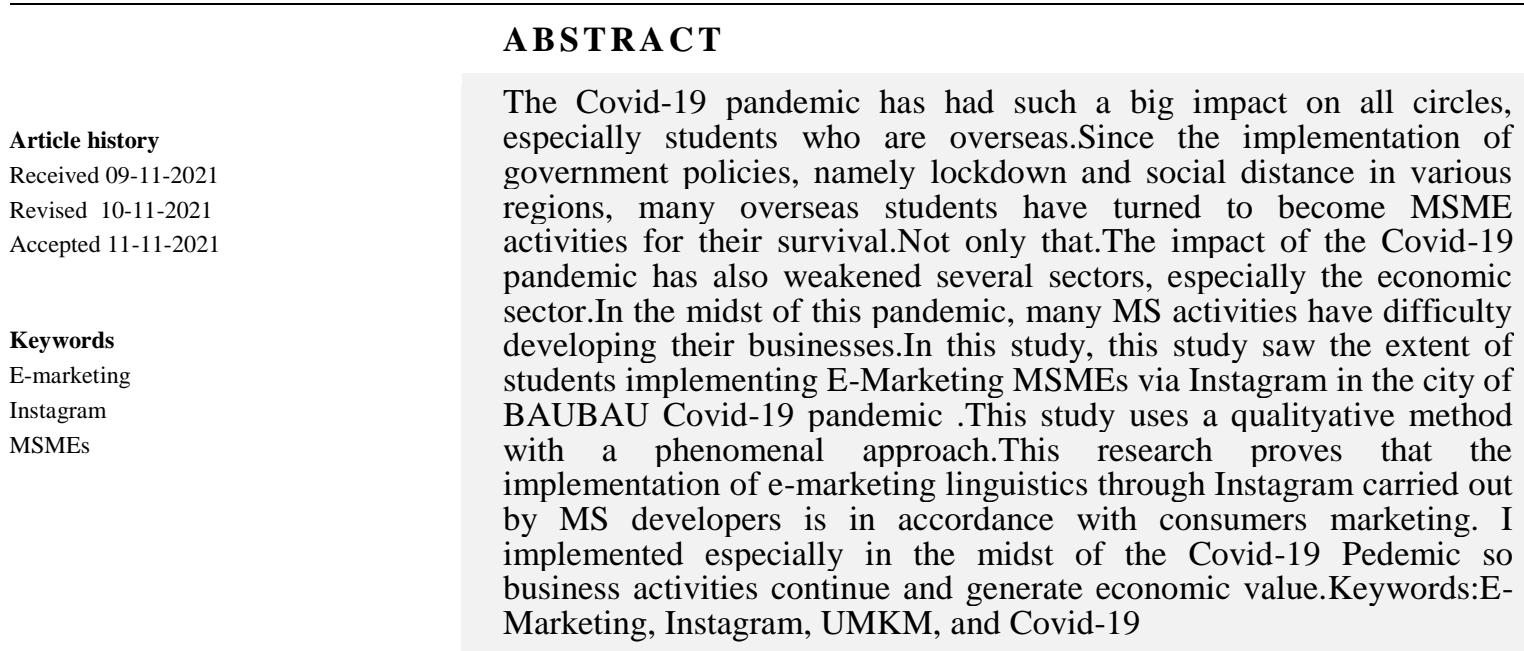

This is an open access article under the CC-BY-SA license.

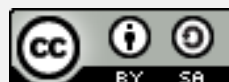

\section{Introduction}

The Covid-19 outbreak has now become a global pandemic after it was announced by the World Health Organization and it's rapid spread-19 a major topic in various countries. In Indonesia, the number of positive people infected with the Corona Virus or Covid-19 is increasing day by day. In Indonesia, the number of patients infected with the corona virus is increasing day by day. On November 28, 2020, there were 527, 999 confirmed Covid-19 victims, with 483 patients recovery. Even though many people have recovered, there are still many victims who have died, namely 16, 646 people. In Southeast Sulawesi alone, the number of customers who confirmed corona positives on November 28, 2020 was 6, 367, with as many patients who recovered, 15, and 17 (Velavan \& Meyer, 2020).

Moody isn't an Investor Service rating agency predicts Indonesias economic growth from 4. 9 percent till 4.8 percent out of 2020. Moody doesn't explain that the corona virus (covid-19) will still slow down economic activity, especially in the first half of this year. The risk of a global recession has also increased. The longer the corona virus outbreak will affect economic activity, a spike in demand will occur and lead to a recession because of the continuous weakening of consumption. Coupled with a prolonged business closed, will reduce income and encourage layoffs (Gondouin, 2020). A semi crisis like this certainly has an impact on various economic sectors, one of which is the existence of consumers that really needs special attention, because MSME- providers are the largest substitutes and CTmen. The role of MSMEs is very important in Indonesian economy. 
Data from the Ministry of Cooperatives and Small Medium Enterprises of Indonesia in 2018 shows that the number of MS business units are $99.9 \%$ of the total business units of 62.9 million units. The absorption capacity of MSMEs is $97 \%$ of the total employment, $89 \%$ of which is in the micro sector, and can contribute $60 \%$ to domestic gross product. The existence of economic turmoil that is so extraordinary that MSMEs are considered capable of facing an economic slowdown related to current conditions. Chairman of Indonesian MS Association (Akumi seller) Ikhsan ngrabatun estimates that the non-ary sector has decreasedThe appeal from the Government regarding social distance which was launched on March 15, 2020 also predicts that it can have a serious impact on MSME products (Kushnir, Mirmulstein, \& Ramalho, 2010).

Therefore, it requires more attention from the government to the UMK sector as the main driver of the nations economy.Not only that, the impact of Covid-19 has also changed the business behavior of entrepreneurs while running their businesses.Although the impact of Covid-19 has been felt by various industrial sectors, it does not mean that MSME players should stop running their business. However, MSMEs can still try to keep running their business through an online system (emarketing) where they will not violate government regulations regarding social distance rules.Through the role of technology, business activities and distribution of goods can still be done.This is done with the aim that MSME business does not just stop and the distribution of goods will continue.

There are new norms for business people when facing the Covid-19 pandemic, which requires business people to be technology literate.This will also apply after Covid-19, which requires recovery of MSME players to even adapt to new norms that require interest in technology.A common problem encountered is that many business actors are familiar with internet technology to develop their business.Even though the use of technology, information and internet networks are increasingly easy to reach and use even for ordinary people.Indonesian society has a variety of creativity, it has the potential to build MES that have high competitiveness.It's just that some people do not know how to build a product to become known and have a wide market potential by utilizing Internet technology (Syuhada \& Gambett, 2013).

This condition is an opportunity that is now being used by technology activities who are also MSME players who adapt technology-based services to carry out online marketing so that it can create a variety of new opportunities.Current technological advances encourage people to carry out activities that are faster and easier.This progress is evident in the field of telecommunications.The existence of this telecommunication advancement makes human relations in terms of communication borders and without obstacles, especially distance.The Internet is one of the advanced in the field of communication technology that is growing so rapidly.The internet provides the benefit of the ease of communication and has particular importance.The existence of the information technology (IT) revolution and communication is always changing from day to day, this also changes the way people do business today (Shafi, Liu, \& Ren, 2020).

Where the digital era can be a crucial point for all human activities, which can support business activities.Business people who are hindered by problems with the lack of knowledge of digital marketing and electronic commerce require people to be able to take advantage of social technology as well.The current digital era cannot be avoided, business people must be able to maximize digital development, because it is possible to mark their products online.

Chasy said that e-marketing is a process in achieving goals related to marketing by relying on electronic communication technology.Also referring to what Harijato said, e-marketing applications are very suitable to be applied to companies that want to increase their market share, because this application can capture more consumers.Again.With e-marketing, it will be maximized in terms of distributing marketing information, both services and goods offered, as well as making it easier for consumers to get the information needed.In addition, applying this marketing strategy will increase the market size of the existing segmentation.So it can be said that e-marketing is an online marketing process through electronic technology, both marketing and services that reach a wider market and build closer relationships with consumers.

To be able to capture market share and consumers, it is appropriate for business actors to better understand the role of the digital world or online sales currently have a big role of the media where 
we cannot travel.Moreover, we see that the digital world is now very loved by the wider community, the following platforms that are often used as media in digital media or social networking.The social media is sometimes have different characteristics. There are media that are only for friendship such as Facebook, Instagram, WhatsApp and Twitter, some have a special purpose to find and build relationships like that offered by Linkedin.Apart from that, there is also more personal media such as electronic mail (e-mail) and text messages.Another thing that business actors can also take advantage of other media such as blogs or personal websites (Knowledge, 2020).

To be able to capture market share and consumers, it is appropriate for business actors to better understand the role of the digital world or online sales currently have a big role of the media where we cannot travel.Moreover, we see that the digital world is now very loved by the wider community, the following platforms that are often used as media in digital media or social networking.The social media is sometimes have different characteristics. There are media that are only for friendship such as Facebook, Instagram, WhatsApp and Twitter, some have a special purpose to find and build relationships like that offered by Linkedin.Apart from that, there is also more personal media such as electronic mail (e-mail) and text messages.Another thing that business actors can also take advantage of other media such as blogs or personal websites (Nadda, Dadwal, \& Firdous, 2015).

Up city of Baubau needs to be an important concern amidst the turmoil of the business world due to the Covid-19 outbreak, namely by digital marketing as a medium.Marketing,Where this utilization becomes a promising potential with the Social Distdancing rules.Thus requiring MSME players to be technologically literate.Seeing this, the author is interested in examining the importance of the use of digital marketing via _ Instagram which has been carried out by one of the MSME activities in the MS-19th, especially the Mass facing.

\section{Theorotocal Framework}

\section{a) Facebook Marketing}

After Search Engine Optimization (SEO) was deemed insufficient for effective marketing on the internet, Web 2.0 or better known as social media was born. Among the popular social media are Facebook, Youtube, Flickr, Twitter, etc. From here comes the term SMO (Social Media Optimization) which is a new technique in online marketing, but that doesn't mean the old technique (SEO) is no longer valid. Combining SEO and SMO techniques for online marketing activities will give extraordinary results (Leung, Bai, \& Stahura, 2015).

Facebook was founded on February 4, 2004, has registered more than 37 million users and thousands of business networks. Facebook has developed a wide variety of applications that users can install. These applications provide added value for Facebook. Many applications have been developed that support businesses and jobs such as selling or buying goods (Facebook, 2011).

The proliferation of social networks such as Facebook opens a very good opportunity for anyone to do marketing activities better and at relatively low cost (Leung et al., 2015)Marketing activities and other business processes using the Facebook social network can also be referred to as ECommerce. Facebook marketing is conducting marketing activities using all the facilities provided by Facebook to increase sales and establish more lasting communication with customers (customer relationships).

Fig. 1. The concept of Facebook Marketing

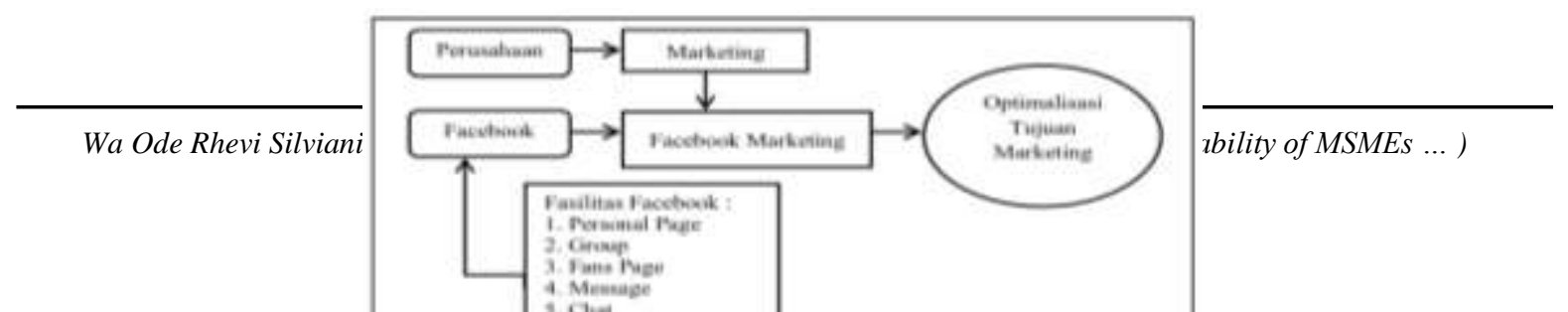




\section{Method}

The research method used in this study is to do quality research. Qualitative methods related to understanding the social world and how to express this understanding using language, sounds, images, personal style, and social rituals (Sugiyono, 2018). Qualitative methods attempt to interpret the meaning in an event of human behavior interaction based on the experiences of participants in certain situations according to the perspective of the researcher himself and to understand the object under depth.This research approach uses a phenomenal approach, in the context of quality research, a phenomenon is something that appears in the researchers, consciousness by being visible and real.Qualitative research with a phenomenal approach aims to bring awareness and deep understanding of how humans experience things.The phenomenal approach is to reveal the meaning of a concept or phenomenon. Experience is based on awareness that occurs in individuals.Here the researcher acts as a facilitator who gives meaning to the reality of the research subject.In this study, met directly with MSMEs and carried out online marketing in Baku City (Sugiyono, 2018).

This study aims to reveal how important the urgency of implementing e-marketing via Instagram strategies affects the economic defense marketing of MSability.The Covid Pedemic 19.

\section{Results and Discussion}

\section{a) Implementation of E-Market Via Instragram on MSability of MSMEs in the face of the Covid-19 Panademic City.}

Implementation means implementing, implementation is related to how the company applies procedures in accordance with the provision of the provisions.Nearly a quarter of Indonesias population actively uses social media Instagram.The social media marketing analysis company based in Warsaw, Poland, NapoleonCat note that the number of Indonesian Instagram users as of November 2019 was 610, 610 million, which was created.6 percent of Indonesias population.As we know that HotoSuite is a content management service system that provides online media services that are connected to various social networking sites such as You Tube, Twitter, Line, FbOK, Whatsapp, etcIn accessing the media, users in Indonesia spend various amounts of time, on average every day using the internet via any device; 7 hours, 59 minutes and 3 hours 26 minutes. The percentage of internet users who use the Instagram platform in Indonesia is $79 \%$ of the total population.At that time the number of Instagram users in Indonesia in 2020 was 63 million, with the percentage of Instagram users being 50.8\% and male as much as $49.2 \%$. When viewed in terms of benefits and also the number of Instagram users in Indonesia, especially in the city of Baubau are MS players as well as social media users who use Instagram.

Based on the interviews that have been conducted, the following has been done by SMEs in Baubau City on implementing e-marketing via Instagram,including:

1. Registering a Brand Account Since the existence of e-commerce, business development has been very fast, so the potential of the economic sector can be maximized in digital trade.The existence of the internet era requires business actors to be more creative in developing ideas using electronic commerce.Over time, ideas to maximize the benefits of internet service will continue to grow, including e-commerce and virtual communities.This is used by MSemic activists in the city of Baubau to develop their businesses, one of which is a home industry culinary business that attracts customers and gets benefits in the mend-19.The UMKM was established on February 12, 2020 with the name of "Renovfood". 


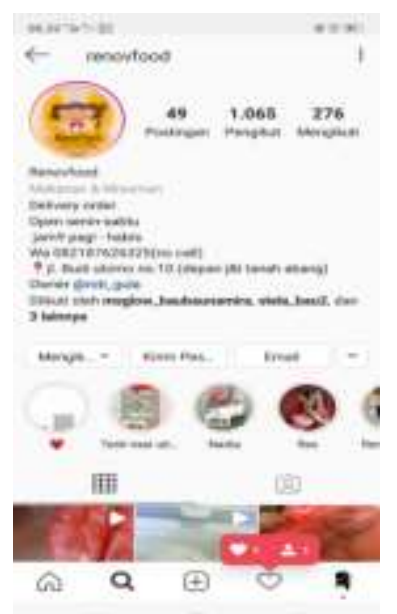

Fig. 2. Picture Profile Instagram renovfood

2. Posting products and providing information about businesses that have been registered for.

Products posted must provide information that consumers can understand, so that consumers should know the type and function of the product appropriately.The purpose of providing information on a product and business characteristics is that the information can be received well by consumers. This can be proven by the way that is done by MSME owners in promoting their business products on Instagram, namely by uploading product photos or on Instagram Feeds by You (Instagram).

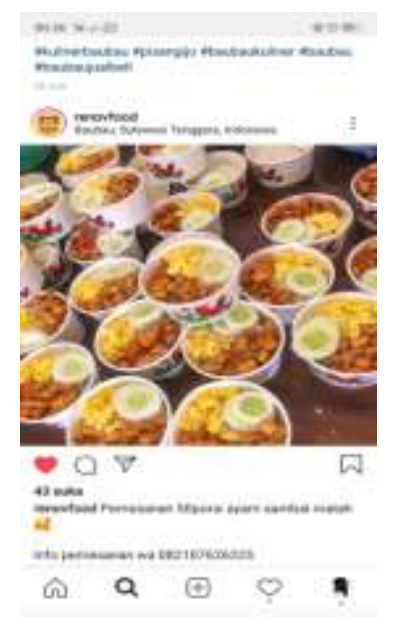

Fig. 3. Picture update story renovfood

By running online marketing through the marketplace via Instagram, it can make it easier for consumers to interact directly with online sellers by registering first by providing a description of each product post that has been produced.Interaction is an action that can influence one another.Therefore, we can conclude that the interaction between business people and consumers will occur if consumers contact business people through the numbers listed on the marketplace that they orders to make transactions.I know business.

\section{b) Sales Strategy}

Currently, the use of social media is not just for posting photos or videos.Social media is also used to selling our businesses. One of the social media that has the most influence on the sales of a business product is Instagram.

Instagram is a social media that has a big and important influence on business.Up to now, Instagram already has 700 million users and every day around 60 million photos are shared and can give 1.6 billion likes Instagram is a social media that has a big and important influence on 
business.Up to now, Instagram already has 700 million users and every day around 60 million photos are shared and can give 1.6 billion likes (Terho, Eggert, Haas, \& Ulaga, 2015).

\section{Conclusion}

1. The following is the sales strategy carried out by Reno food MS owners in the city of Baubau

Using Branded Hashtags Even though Instagram is a social media that prioritizes visuals, there are non-visual elements that need to be added to the Instagram brands.One popular technique is branded hashtags.Branded hashtags are used by the owner of Renofvood in their posts, namely \#lunch \#quably lunchboxb ricebanktebau une.

Prometo Business through Cooperation with Outside Parties Business people try to increase products through the Instagram platform in various ways.One of them is through collaboration with outside parties, namely by promoting mutual accounts to the audience. The goal is to accelerate the number of followers of each of the collaborating accounts.Eka Noviastuty as the owner of UMKM Reno food, in developing his business and implementing E-Market through the Instagram feature always collaborates with outsiders, one of which is called Arkb or Influencer.In cooperation with outside parties, Eka Noviastuty invites one of the quite celebrities influential in the city of Baubau to collaborate in the form of sponsors content on their own product.Of course this is done because of an agreement between both parties that are mutually beneficial for them.

\section{Impact of E-Marketting via Instagram amid the Covid-19 Pandemic in Baubau City}

To be able to run a business in the midst of the Covid-19 Pandemic cannot be separated from the marketing efforts carried out by MSME entrepreneurs in Baubau City using the emarketing business via Instagram. The following are the positive impacts felt by MSME entrepreneurs, namely Renovfood in the city of Baubau:

Based on this, it can be concluded that the application of the online e-marketting business system via Instagram by MSME Entrepreneurs in the city of Baubau in the midst of the Covid-19 pandemic is really being used by MSMEs. Technological advances and the era of the industrial revolution 4.0 have an important role in industrial competition. However, the intership revolution must also be implemented where MSME players in Baubau City are required to be literate towards technology, that after the Covid-19 pandemic there will be new norms in their business activities related to the use of more enhanced technology. Therefore, the strong desire to learn that is applied by the informants is a form of internship revolution, so that by taking advantage of opportunities along with technological developments and the industrial revolution, it is hoped that business actors will be able to take advantage of opportunities and improve the economic level of a country in the midst of the Covid19 pandemic currently facing the world and in particular Indonesia.

\section{Acknowledgment}

Based on the analysis and discussion of the results of interviews with informants relating to the urgency of e-marketing on the sustainability of MSMEs in Baubau City, the impact of the Covid-19 Pandemic, the following conclusions can be drawn:

This research proves that the implementation of e-marketing via Instagram by MSME entrepreneurs is in accordance with the procedure. Starting from registering a business, posting products, adding important information, and interacting with consumers.

This research proves that implementing e-marketing has had a positive impact amid the Covid-19 pandemic on the economic resilience of MSMEs in Baubau City by continuing to carry out the production process and continuing to distribute goods to consumers and continuing to carry out social distancing, of course this impact is not far from a role. technology that makes it easier for MSME entrepreneurs to keep running their business.

The use of e-marketing through Instagram is deemed necessary, especially in the midst of the Covid-19 Pandemic which has an impact on the weakening of the economy in all sectors and 
especially the industrial sector, this can ensure the sustainability of MSME businesses because it is in accordance with the concept of the industrial revolution 4.0.

\section{References}

Facebook. (2011). Best Practice Guide Marketing on Facebook. ZBW Mediatalk.

Gondouin, B. (2020). COVID-19. Nephrologie et Therapeutique. https://doi.org/10.1016/S17697255(20)30419-3

Knowledge, M. (2020). Marketing channels. In CIM Revision Cards: Marketing Communications 04/05. https://doi.org/10.4324/9780080546674-9

Kushnir, K., Mirmulstein, M. L., \& Ramalho, R. (2010). Micro, Small, and Medium Enterprises Around the World: How Many Are There, and What Affects the Count? World Bank, IFC.

Leung, X. Y., Bai, B., \& Stahura, K. A. (2015). The Marketing Effectiveness of Social Media in the Hotel Industry: A Comparison of Facebook and Twitter. Journal of Hospitality and Tourism Research. https://doi.org/10.1177/1096348012471381

Nadda, V. K., Dadwal, S. S., \& Firdous, A. (2015). Social media marketing. In Handbook of Research on Integrating Social Media into Strategic Marketing. https://doi.org/10.4018/978-1-4666-8353-2.ch021

Shafi, M., Liu, J., \& Ren, W. (2020). Impact of COVID-19 pandemic on micro, small, and medium-sized Enterprises operating in Pakistan. Research in Globalization. https://doi.org/10.1016/j.resglo.2020.100018

Sugiyono. (2018). Metode Penelitian Kombinasi (mixed Methods). In Alfabet.

Syuhada, A. A., \& Gambett, W. (2013). Online Marketplace for Indonesian Micro Small and Medium Enterprises based on Social Media. Procedia Technology. https://doi.org/10.1016/j.protcy.2013.12.214

Terho, H., Eggert, A., Haas, A., \& Ulaga, W. (2015). How sales strategy translates into performance: The role of salesperson customer orientation and value-based selling. Industrial Marketing Management. https://doi.org/10.1016/j.indmarman.2015.02.017

Velavan, T. P., \& Meyer, C. G. (2020). The COVID-19 epidemic. Tropical Medicine and International Health. https://doi.org/10.1111/tmi.13383 